\title{
DETEKSI GULMA BERDASARKAN WARNA HSV DAN FITUR BENTUK MENGGUNAKAN JARINGAN SYARAF TIRUAN
}

\author{
Hurriyatul Fitriyah $^{* 1}$, Rizal Maulana ${ }^{2}$ \\ ${ }^{1,2}$ Fakultas Ilmu Komputer, Universitas Brawijaya Malang \\ Email: ${ }^{1}$ hfitriyah@ub.ac.id, ${ }^{2}$ rizal_lana@ub.ac.id \\ "Penulis Korespondensi
}

(Naskah masuk: 16 Februari 2021, diterima untuk diterbitkan: 18 Oktober 2021)

\begin{abstract}
Abstrak
Gulma merupakan tanaman pengganggu dalam lahan pertanian. Herbisida merupakan obat yang efektif membunuh gulma tersebut. Penyemprotan herbisida harus tepat sasaran kepada gulma saja dan tidak mengenai tanaman. Penelitian ini membuat sistem yang dapat mendeteksi gulma secara otomatis di antara tanaman pada lahan pertanian riil. Sistem ini menggunakan gambar lahan pertanian riil dimana tanaman tampak utuh (daun dapat lebih dari satu) yang diambil menggunakan kamera dengan posisi vertikal menghadap ke bawah. Algoritma yang dibuat menggunakan segmentasi berdasarkan warna hijau dalam ruang warna HSV untuk mendeteksi daun, baik gulma maupun tanaman pada beragam pencahayaan. Sebanyak tiga fitur bentuk domain spasial digunakan untuk membedakan gulma dengan tanaman yang memiliki karakteristik bentuk daun yang berbeda. Fitur bentuk yang digunakan adalah Rectangularity, Edge-to-Center distances function, dan Distance Transform function. Klasifikasi gulma dan tanaman menggunakan metode Jaringan syaraf tiruan (JST) yang dapat dilatih secara offline. Dari 149 tanaman yang terdeteksi dimana $70 \%$ sebagai data training, $15 \%$ data validasi dan $15 \%$ data uji, didapati akurasi pengujian sebesar $95.46 \%$.
\end{abstract}

Kata kunci: gulma, HSV, fitur bentuk, jaringan syaraf tiruan

\section{WEED DETECTION IN HSV COLOR-SPACE BASED ON SHAPE FEATURES USING ARTIFICIAL NEURAL NETWORK}

\begin{abstract}
Weed is a major challenge in a crop plantation. A herbicide is the most effective substance to kill this unwanted vegetation. Spraying the herbicide must be done carefully to target the weeds only. Here in this research, we develop an algorithm that detects weeds among the plants based on the shape of their leaves. The detection is based on images that were acquired using a camera. The leaves of weeds and plants were detected based on their green color using segmentation in HSV color-space as it is more effective to detect objects in various illumination. Three shape features were extracted, which are Rectangularity that is based on Rectangularity, Edge-to-Center distance function, and Distance Transform function. Those features were fed into a learning algorithm, Artificial Neural Network (ANN), to classify whether it is the plant or the weed. The testing on the weed classification in a real outdoor environment showed 95.46\% accuracy using a total of 149 detected plants (70\% as training data, $15 \%$ as validation data, and $15 \%$ as testing data).
\end{abstract}

Keywords: weeds, HSV, shape features, artificial neural network

\section{PENDAHULUAN}

Dalam budidaya tanaman, gulma merupakan tanaman liar yang keberadaannya tidak diinginkan oleh petani. Keberadaan tanaman pengganggu ini dapat mengambil nutrisi dari dalam tanah yang mengakibatkan tanaman asli tidak dapat tumbuh dengan baik. Secara umum, gulma dikategorikan menjadi 3 jenis berdasarkan bentuk daunnya, yakni gulma berdaun lebar, gulma berdaun sempit dan teki (Barus, 2003). Contoh dari gulma berdaun lebar adalah Ceplukan (Physalis angulata L.), Wedusan (Ageratum conyzoides L.), Sembung hair (Mikania michranta), dan Putri malu (Mimosa pudica). Contoh gulma berdaun sempit antara lain Panicum repens, Eleusine indica, dan Axonopus compressus. Contoh gulma berdaun teki adalah Sawah teki (Cyperus rotundus), Udelan (Cyperus kyllingia), dan Scirpus maritimus.

Keberadaan gulma terbukti mampu mempengaruhi pertumbuhan tanaman dan 
menurunkan produksi pertanian (Mangoensoekarjo \& Soejono, 2019) (Moenandir, 2010). Populasi gulma dapat dikendalikan dengan dua cara, yakni penyiangan yang dilakukan secara manual dan penyemprotan herbisida. Cara kedua adalah metode yang lebih banyak digunakan karena efektif membunuh gulma dengan dilakukan oleh sedikit pekerja (Apriadi, Sembodo, \& Susanto, 2013).

Herbisida memiliki jenis yang disesuaikan dengan tipe daun gulma. Sebagai contoh untuk gulma berdaun lebar yakni Echinocloa Crusgali yang banyak ditemukan di sawah padi, herbisida yang paling cocok digunakan adalah tipe 2,4-D (Kadir, 2007), (Purnamasari, Tyasmoro, \& Sumarni, 2017).

Penyemprotan secara manual memiliki kekurangan yakni tersemprotnya tanaman budidaya secara tidak sengaja. Selain merusak tanaman, aktivitas manual tersebut juga membutuhkan pekerja dengan pengalaman dan pengetahuan yang beragam. Robot pertanian kini mulai banyak dikembangkan untuk budidaya lahan pertanian secara lebih efektif dan efisien terutama untuk lahan besar. Robot penyemprot gulma merupakan jenis dari robot pertanian yang berfungsi untuk melakukan penyemprotan hanya kepada gulma. Robot ini dapat dikendalikan secara manual atau otomatis. Robot penyemprot gulma otomatis secara umum menggunakan data input berupa gambar tampak atas dari tanah yang diambil secara vertikal oleh kamera. Gambar tersebut kemudian diproses menggunakan beragam metode Pengolahan Citra Digital untuk mendeteksi keberadaan, jenis dan posisi dari gulma untuk dilakukan penyemprotan yang sesuai. Robot tersebut kemudian menyemprotkan herbisida yang disimpan dalam tangki penyimpan tepat ke arah gulma (Slaughter, Giles, \& Downey, 2007).

Beragam metode klasifikasi gulma telah dilakukan antara lain oleh (Sarvini, Sneha, Suka, Susmitha, \& Kumaraswamy, 2019) menggunakan SVM (Support Vector Machine), ANN (Artificial Neural Network) and CNN (Convolutional Neural Network). Fitur bentuk yang digunakan antara lain area, keliling, panjang diameter major, panjang diameter minor, Eccentricity, Data latih yang digunakan adalah sejumlah 1155 tanaman dan 1155 gulma. Penelitian tersebut menemukan bahwa CNN mendapatkan akurasi yang paling tinggi.

Penelitian lain oleh (Bawden, et al., 2017) mendeteksi gulma berdasarkan warna daun dengan kombinasi ruang-warna RGB, HSV, LUV dan LAB. Penggunaan lebih dari satu ruang warna terbukti lebih akurat dalam pendeteksian gulma. Penelitian tersebut menggunakan fitur LBP (Local Binary Pattern) dan Covanriance sebagai fitur klasifikasi dari Convex-hull gulma.

Gambar yang dapat diambil di lahan pertanian oleh robot umumnya merupakan gambar tampak atas yang diambil oleh kamera dengan posisi vertikal menghadap ke bawah. Pada posisi tampak atas, bagian tanaman atau gulma yang mudah difiuanalisa lebih lanjut adalah daun. Beberapa penelitian klasifikasi jenis daun berdasarkan gambar menggunakan fitur bentuk dan tekstur antara lain (Beghin T., Cope J.S., Remagnino P., Barman S., 2010). Penelitian lain oleh (Kadir, A., Nugroko, L.E., Susanto, A., Santosa, P.I., 2011) meneliti fitur warna dan juga perbandingan luas pembuluh sebagai fitur pembeda jenis daun selain bentuk dan tekstur.

Penelitian-penelitian tersebut menggunakan fitur bentuk untuk mengklasifikasi tanaman berdasarkan bentuk satu helai daun saja. Daun tanaman dipetik dan difoto tampak atas dengan pencahayaan yang sudah tetap (fixed). Penelitian ini memberikan kontribusi terhadap pendeteksian jenis tanaman berdasarkan daun riil yang ada di lahan pertanian. Daun tersebut tidak dipetik namun dibiarkan menancap di tanaman yang tumbuh di tanah. Ukuran tanaman maupun gulma juga dapat bervariasi. Bentuk tanaman atau gulma yang terdiri dari banyak daun juga menghasilkan bentuk tanaman tampak atas yang bervariasi bentuknya meski dalam satu kategori. Penelitian ini juga mengatasi kondisi pencahayaan bervariasi yang riil di lahan pertanian baik cahaya rendah dan tinggi. Dengan beberapa kompleksitas tersebut, tidak semua fitur bentuk dapat digunakan untuk membedakan tanaman dengan gulma. Fitur bentuk harus dipilih berdasarkan karakteristik utama dari bentuk tanaman tampak atas.

\section{METODE PENELITIAN}

Dalam penelitian ini, tanaman yang digunakan adalah bawang merah yang banyak dibudidayakan di persawahan di Indonesia. Gulma yang ditemui di lahan tersebut adalah gulma Drymaria Cordata yang di daerah Jawa biasanya dikenal dengan nama Cemplonan. Tanaman dan gulma tersebut memiliki bentuk daun yang berbeda. Daun bawang merah jika dilihat dari atas memiliki bentuk pipih dan memanjang. Gulma Drymaria Cordata memiliki daun kecil dan bulat.

Foto tanaman dan gulma diambil menggunakan kamera CCD. Gambar yang ditangkap memiliki warna RGB. Gambar tersebut kemudian diproses menggunakan Pengolahan citra digital yakni konversi warna RGB ke HSV, segmentasi dengan Thresholding untuk mendapatkan region daun, dan deteksi tepian Canny untuk mendapatkan tepian daun. Beberapa fitur bentuk di-ekstraksi dari region dan tepi masing-masing daun yang tersegmentasi. Nilai dari setiap fitur yang di-ekstraksi diumpankan ke algoritma klasifikasi, yakni Jaringan Syaraf Tiruan (JST). Metode JST dipilih karena perhitungan penentuan kelas-nya sederhana dan ringan saat nantinya diterapkan pada embedded system robot. 


\subsection{Pengambilan Gambar}

Kamera CCD diletakkan secara vertikal menghadap ke bawah dengan sudut $90^{\circ}$. Kamera diletakkan pada jarak tetap setinggi 1.5 meter dari tanah. Tata letak ini disesuaikan dengan desain robot penyemprot yang akan melakukan scanning gulma dari atas lahan. Sudut tegak juga dipilih sebab bentuk daun dapat terlihat berubah dari bentuk sebenarnya pada posisi tampak miring. Jarak yang tetap juga dibutuhkan untuk menjaga pixel-to-cm ratio. Ilustrasi setting pengambilan gambar diperlihatkan pada Gambar 1.

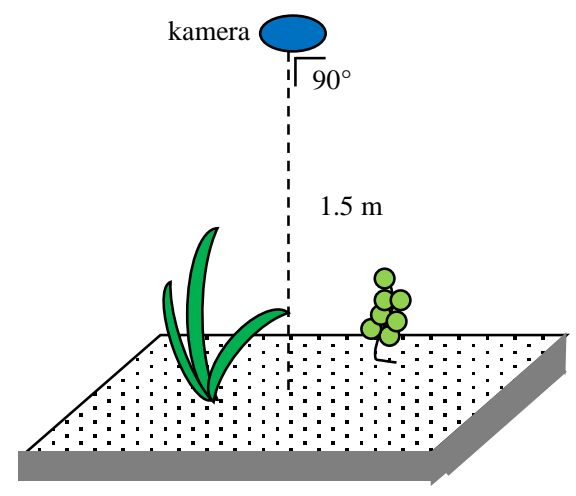

Ukuran tanaman dan gulma yang diambil beragam. Beberapa tanaman bawang merah memiliki ukuran lebih besar dari gulma dan beberapa lebih kecil dari gulma. Variasi ukuran ini bertujuan agar algoritma yang dikembangkan mampu mendeteksi gulma di antara tanaman dengan umur tanaman yang beragam. Pencahayaan gambar juga beragam. Beberapa gambar diambil pagi hari dan beberapa gambar diambil siang hari. Hal ini bertujuan agar algoritma yang dikembangkan mampu mendeteksi gulma kapan saja.

Contoh beberapa hasil gambar yang diambil diperlihatkan pada gambar 2. Pada gambar 2(a), tanaman bawang berukuran lebih kecil dari gulma dan diambil pada pagi hari dengan pencahayaan rendah. Gambar 2(b) menunjukkan kondisi ukuran tanaman bawang merah yang lebih besar dari gulma dan diambil pada siang hari dengan pencahayaan tinggi. Cahaya untuk pengambilan gambar berasal dari matahari. Tidak ada cahaya khusus yang digunakan saat pengambilan gambar. Total gambar yang diambil adalah sejumlah 78 gambar.

Kondisi daun pada beberapa gambar juga terlihat tidak utuh. Hal ini sesuai yang ditunjukkan pada gambar 2(a) untuk gulma dan gambar 2(b) untuk daun bawang merah yang tidak terlihat utuh. Beberapa kondisi daun juga terlihat utuh seperti bawang merah pada gambar 2(a) dan gulma pada gambar 2(b). Dalam satu gambar juga dapat terdapat lebih dari satu tanaman atau gulma seperti terlihat pada gulma di gambar 2(b). Kondisi daun tanaman bawang merah dan gulma yang bervariasi ini diambil agar algoritma yang dibuat juga mampu melakukan deteksi gulma dan tanaman dalam kondisi riil di lahan pertanian. Ukuran gambar yang diambil adalah 240x320 piksel.

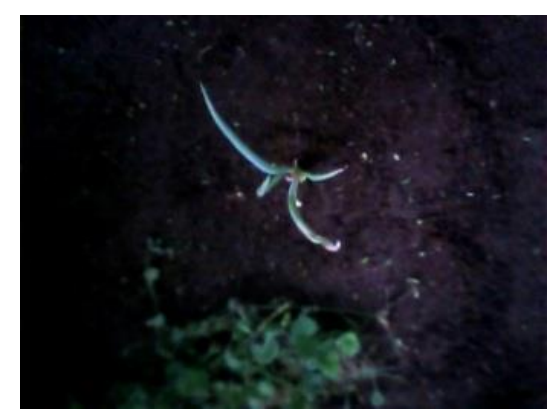

(a)

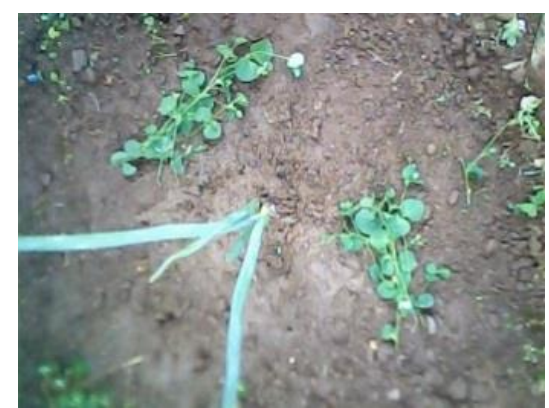

(b)

Gambar 2. Contoh gambar yang diambil; (a) pencahayaan rendah, ukuran tanaman lebih kecil dari gulma, (b) pencahayaan tinggi, ukuran tanaman lebih besar dari gulma.

\subsection{Ekstraksi Fitur Bentuk menggunakan Pengolahan Citra Digital}

Metode Pengolahan Citra Digital digunakan untuk meng-ekstraksi fitur bentuk dan daun. Langkah pertama adalah melakukan konversi warna dari warna asal RGB ke HSV (Hue, Saturation, Value). Lengkah berikutnya dalah melakukan segmentasi daun dari tanah dalam ruang warna HSV tersebut. Metode yang dipilih adalah Thresholding dengan batas yang dipilih secara manual atau otomatis menggunakan Otsu's Thresholding pada masing-masing channel.

Hasil proses Thresholding adalah gambar biner yang bernilai 1 untuk daun dan 0 untuk non-daun. Hasil binerisasi setiap channel kemudian digabungkan dengan operasi AND. Dua buah filter kemudian diterapkan pada gambar biner tersebut untuk menghilangkan kesalahan segmentasi. Dua filter yang digunakan adalah Median Filter dan Area Filter. Hasil kedua filter tersebut adalah region daun dari tanaman dan gulma.

Langkah berikutnya adalah pencarian tepi menggunakan metode deteksi tepi Sobel. Langkah berikutnya adalah menemukan Distance Transform dari region daun tanaman dan gulma. Fitur-fitur bentuk diambil dari region, tepi, dan nilai Distance Transform setiap daun yang terdeteksi. Banyak fitur 
bentuk yang dapat digunakan, namun penelitian ini memilih 3 fitur bentuk saja, yakni Rectangularity, Edge-to-Center Function, dan Distance Transform Function. Tahap ekstraksi fitur ditunjukkan pada Gambar 3.

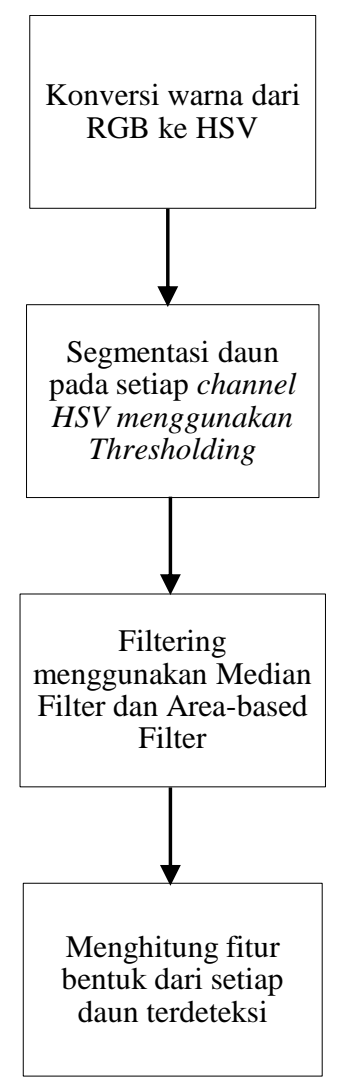

Gambar 3. Tahap pengolahan citra digital untuk ekstraksi fitur

\section{Konversi warna dari RGB ke HSV}

Gambar RGB merupakan data hasil akuisisi oleh kamera. Ruang warna RGB menunjukkan informasi warna dari setiap piksel gambar berupa nilai intensitas grayscale dari 0-255. Ruang warna RGB memiliki kekurangan bahwa informasi warna dapat bercampur dengan informasi tingkat kecerahan. Target utama dalam proses segmentasi adalah deteksi daun. Daun mudah dideteksi berdasarkan warna hijau-nya. Warna hijau tersebut dalam RGB memiliki nilai yang bervariasi tergantung kondisi pencahayaan. Untuk itu diperlukan sebuah ruang warna yang mampu memilah komponen warna dan komponen kecerahan dari sebuah gambar.

Ruang warna yang mampu memisahkan komponen warna, kecerahan (brightness) dan juga kemurnian warna adalah HSV. H yang merupakan Hue menunjukkan komponen warna, $\mathrm{S}$ yang merupakan Saturation menunjukkan komponen kemurnian warna, dan $V$ yang merupakan Value menunjukkan komponen kecerahan. Hue merupakan komponen warna yang tidak terpengaruh oleh cahaya dan tingkat kemurnian, sehingga daun akan mudah terdeteksi dengan menggunakan batas warna hijau dalam Hue. Nilai Hue juga tidak terpengaruh oleh pencahayaan yang berbeda, sehingga daun mudah terdeteksi meski dalam kondisi cahaya rendah seperti Gambar 2(a) atau cahaya tinggi seperti Gambar 2(b).

Persamaan konversi warna dari RGB ke HSV ditunjukkan pada kode program berikut (Smith, A. R., 1978). Persamaan-persamaan tersebut menggunakan range 0-1 dari masing-masing nilai $\mathrm{R}$, $\mathrm{G}$ dan $\mathrm{B}$, untuk menghasilkan range $0-1$ juga pada masing-masing nilai $\mathrm{H}, \mathrm{S}$ dan $\mathrm{V}$.

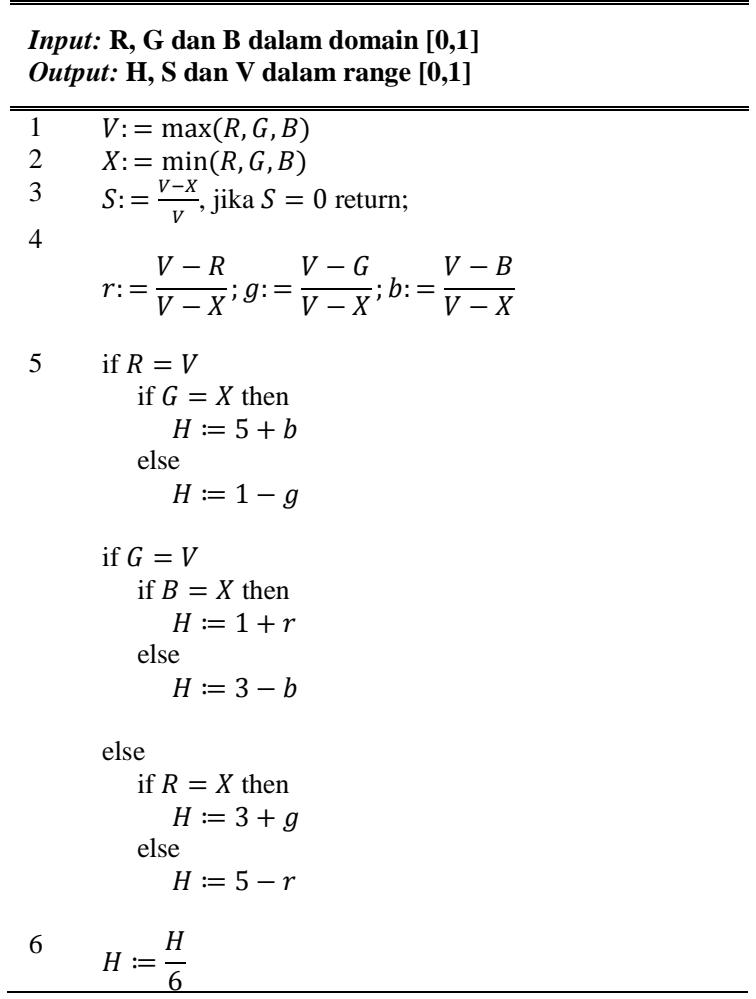

2. Segmentasi daun menggunakan Thresholding

Hasil konversi warna dari RGB ke HSV tersebut kemudian digunakan untuk proses segmentasi. Tujuan dari proses ini adalah untuk mendapatkan area daun saja. Background yang ditangkap oleh kamera dalam penelitian ini adalah tanah sebab posisi kamera adalah menghadap ke bawah.

Dalam pencarian area daun, jenis segmentasi yang dipilih adalah Thresholding. Metode ini dipilih sebab ringan dalam komputasi karena hanya menggunakan if-else. Proses thresholding dilakukan pada masing-masing channel $\mathrm{H}, \mathrm{S}$ dan $\mathrm{V}$.

Batas atau threshold pada channel $\mathrm{H}$ dipilih berdasarkan range warna Hijau pada color-wheel yakni pada derajat $60^{\circ}-180^{\circ}$. Dalam range $[0,1]$ nilai derajat tersebut setara dengan 0.17-0.5. Batas pada channel $\mathrm{S}$ dipilih berdasarkan tingkat kemurnian warna dari daun tumbuhan yang tinggi. Meski 
demikian, pengambilan gambar dalam cahaya tinggi mengakibatkan warna hijau dari daun lebih pudar. Oleh karena itu, batas yang digunakan untuk $\mathrm{S}$ adalah 0-0.8 dalam range $[0,1]$.

Batas pada channel $\mathrm{V}$ dipilih secara otomatis menggunakan metode Otsu's Thresholding. Metode ini menghitung batas secara otomatis berdasarkan between-class variance dan within-class variance. Batas yang dipilih adalah nilai intensitas yang memiliki nilai within-class variance terendah yang bersamaan memiliki nilai between-class variance tertinggi. Pemilihan batas secara adaptif ini dipilih sebab pengambilan gambar dilakukan secara outdoor. Cahaya dalam kondisi tersebut sangat bervariasi dari rendah ke tinggi seperti yang ditampilkan pada Gambar 2, sehingga dibutuhkan batas pada channel $\mathrm{V}$ yang adaptif pula.

Hasil dari masing-masing segmentasi adalah gambar biner bernilai 1 untuk piksel yang berpotensi sebagai daun dan 0 untuk non-daun. Ketiga gambar biner tersebut kemudian digabungkan menggunakan operasi AND. Operasi tersebut menunjukkan bahwa sebuah piksel dianggap sebagai daun jika memenuhi ketiga batas dalam Thresholding.

Proses konversi warna dan segmentasi untuk mendapatkan kandidat daun diperlihatkan pada Gambar 4. Contoh pengolahan citra digital tersebut dilakukan pada Gambar 2(a). Gambar 4(a), 4(b) dan 4(c) adalah masing-masing komponen $\mathrm{H}, \mathrm{S}$ dan $\mathrm{V}$ dari hasil konversi. Gambar 4(d), 4(e), dan 4(f) merupakan hasil proses segmentasi dengan metode thresholding untuk masing-masing komponen $\mathrm{H}, \mathrm{S}$ dan V. Penggabungan ketiga hasil segmentasi menggunakan operasi AND diperlihatkan pada Gambar 4(g). Hasil pada Gambar 4(g) menunjukkan bahwa daun-daun baik tanaman maupun gulma sudah teridentifikasi meski memiliki beberapa noise yang perlu dihilangkan.

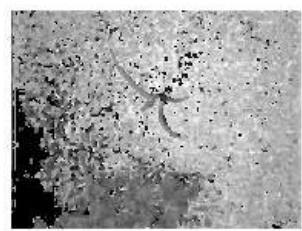

(a)

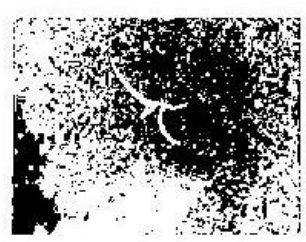

(d)

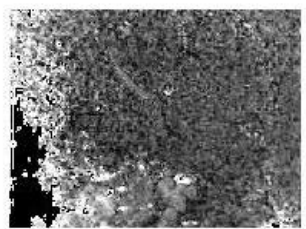

(b)

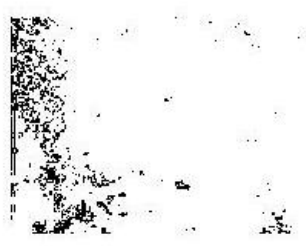

(e)

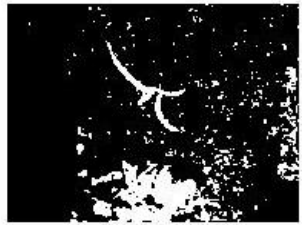

(g)

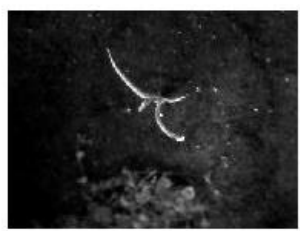

(c)

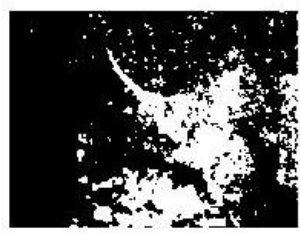

(f)

Gambar 4. Segmentation process in HSV color-space; (a) Hue, (b) Saturation, (c) Value, (d) Segmented Hue, (e) Segmented Saturation, (f) Segmented Value, (g) AND operation of all 3 segmented component

\section{Filtering}

Hasil segmentasi umumnya masih memiliki beberapa kesalahan pendeteksian object of interest. Dua jenis kesalahan segmentasi dalam penelitian ini adalah piksel daun yang dideteksi sebagai non-daun, dan piksel non-daun yang dideteksi sebagai daun. Filter digunakan untuk menghilangkan kesalahan pendeteksian tersebut. Penelitian ini menggunakan Median Filter dengan ukuran window 5x5 untuk menghilangkan kesalahan yang bersifat granular. Filter ini mengambil nilai Median dari semua piksel dalam satu window untuk menggantikan nilai piksel di center dari window. Filter ini umumnya digunakan untuk menghilangkan noise yang bersifat impulsive seperti salt-pepper noise. Derau bersifat salt dalam penelitian ini adalah piksel non-daun yang terdeteksi sebagai daun. Derau bersifat pepper dalam penelitian ini adalah piksel daun yang terdeteksi sebagai non-daun. Filter ini memiliki keunggulan tidak banyak merubah bentuk object of interest dibandingkan penggunaan Morphological Filter. Hal tersebut penting sebab bentuk daun akan di-ekstraksi fitur-nya guna proses klasifikasi.

Filter kedua yang digunakan adalah Area-based Filter. Filter ini diterapkan dengan melakukan pemberian label terlebih dahulu pada connectedcomponent yang terdeteksi pas gambar hasil 
segmentasi. Beberapa piksel dengan label yang sama akan dianggap sebagai sebuah Blob. Area blob yang kecil akan dihilangkan sebab dinilai bukan daun. Dalam gambar yang diambil, daun tanaman berukuran besar dengan ukuran area minimal 500 piksel. Nilai ini kemudian digunakan sebagai batas untuk memfilter area yang dianggap sebagai nondaun. Penggunaan filter kedua memiliki kelemahan dimana daun tanaman atau gulma yang masih kecil akan dihilangkan dan tidak di-analisa lebih lanjut. Namun hal ini tetap dilakukan sebab tanaman/gulma yang masih kecil belum memiliki bentuk daun yang sama dengan tanaman/gulma yang besar.

Hasil proses filtering dari Gambar 4(g) ditunjukkan pada Gambar 5. Hasil penerapan median filter ditunjukkan pada Gambar 5(a). Penerapan filter kedua yakni Area filtering dari Gambar 5(a) ditunjukkan pada Gambar 5(b). Dari hasil akhir tersebut Gambar 5(b) tersebut terlihat hanya daun tanaman dan gulma yang terdeteksi untuk selanjutnya diterapkan analisa bentuk.

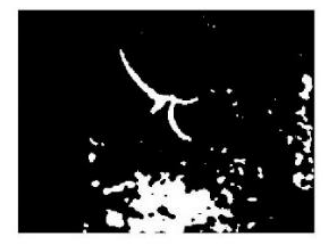

(a)

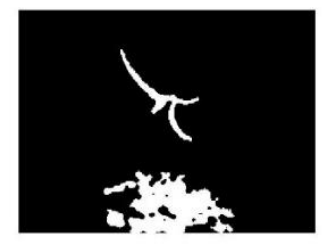

(b)
Gambar 5. Hasil filtering; (a) menggunakan Median Filter, and (b) menggunakan Area Filter berdasarkan ukuran connectedcomponents

\section{Perhitungan fitur bentuk}

Beberapa fitur bentuk yang umum digunakan antara lain Eccentricity, principal axis (major dan minor), minimum bounding rectangle, circularity ratio, Rectangularity, convexity, solidity, Euler Number, centroid distance function, contour curvature, area function, chord length function (Mingqiang, Y., Kidiyo, K. Joseph, R., 2008). Penelitian ini memilih fitur yang dapat digunakan untuk beragam ukuran dari satu kategori tanaman. Fitur seperti minimum bounding rectangle, principal axis tidak dapat digunakan karena ukuran dan bentuk tanaman atau gulma sangat bervariasi. Fitur bentuk yang mengambil nilai dari arah sudut tertentu juga tidak dapat digunakan dalam penelitian ini sebab daun tanaman dan gulma menjalar tidak menentu ke segala arah.

Pada tanaman bawang merah, dari hasil pendeteksian didapati bahwa daun yang terdeteksi bisa hanya satu helai saja. Bentuk daun bawang adalah pipih dan memanjang ke beragam arah. Contoh hasil deteksi daun tanaman bawang merah ditunjukkan pada Gambar 6. Pada Gambar 6(a) terlihat contoh hasil deteksi berupa satu lembar daun. Gambar 6(b) menunjukkan contoh daun bawang dengan bentangan daun ke segala arah, sedangkan Gambar 6(c) menunjukkan contoh bentangan ke segala arah. Keragaman ini juga ditambah dengan ukuran daun bawang yang bervariasi dari kecil hingga besar.

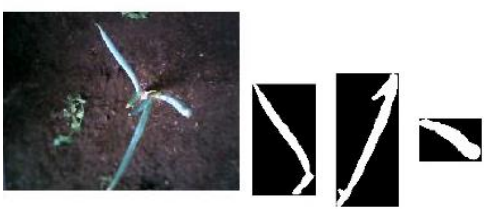

(a)
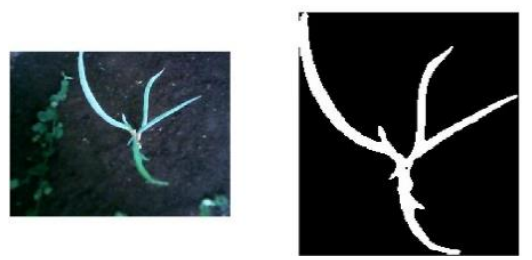

(b)
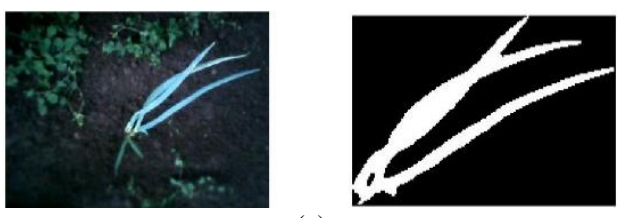

(c)

Gambar 6. Variasi bentuk daun bawang merah yang terdeteksi; (a) hanya satu helai daun terdeteksi, (b) daun membentang ke segala arah, dan (c) daun membentang ke satu arah.

Pada tanaman Cemplonan, arah jalar tanaman ini juga beragam ke segala arah. Beberapa daun tanaman tersebut menjalar membentuk lingkaran namun terkadang memanjang ke satu arah. Hasil beberapa deteksi daun gulma ini ditunjukkan pada Gambar 7. Contoh daun menjalar memanjang ditunjukkan pada Gambar 7(a), sedangkan daun gulma yang mengumpul ditunjukkan pada Gambar 7(b).

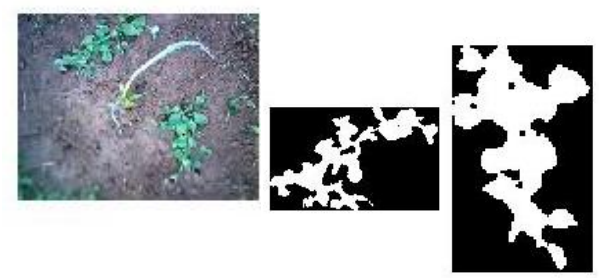

(a)

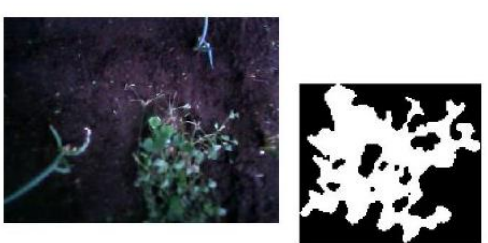

(b)

Gambar 7. Variasi bentuk daun gulma yang terdeteksi; (a) daun menjalar memanjang, (b) daun menjalar melingkar

Dengan mempertimbangkan variasi bentuk dari daun tanaman bawang merah dan variasi bentuk dari 
daun tanaman gulma Cemplonan, maka terdapat 3 fitur yang digunakan. Fitur tersebut dipilih dengan mempertimbangkan ukuran yang beragam dari daun terdeteksi. Fitur yang bersifat directional yang mempertimbangkan arah tidak digunakan dalam penelitian ini, sebab arah bentang daun yang beragam. Fitur yang digunakan adalah Rectangularity, Edge-to-center function, dan Distance-transform function.

Rectangularity adalah perbandingan antara jumlah piksel area daun $A_{s}$ terhadap area Bounding box $A_{R}$. Persamaan fitur pertama ini ditunjukkan pada Persamaan 1. Fitur ini dipilih mengingat bentuk daun gulma yang bulat yang cenderung mengisi ruangan bounding box dibandingkan bentuk daun tanaman bawang yang pipih. Contoh perbandingan jumlah piksel objek dari daun terdeteksi terhadap luas Bounding Box dari gambar 5 dapat dilihat pada Gambar 8.

$$
\text { Rectangularity }=\frac{A_{S}}{A_{R}}
$$
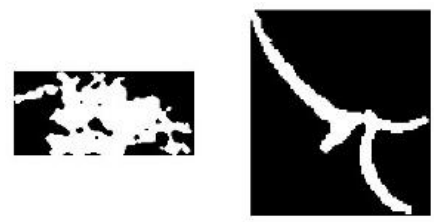

Gambar 8. Rectangularity sebagai perbandingan jumlah piksel daun terdeteksi terhadap area Bounding box

Fitur kedua yang digunakan adalah Edge-tocenter function yakni fungsi statistik yang diambil dari perhitungan jarak Euclidian Distance antara semua tepian (edge) dan titik tengah (center). Tepian objek dideteksi menggunakan operator Sobel yang sederhana sebab deteksi dilakukan pada gambar biner. Nilai center didapatkan mengunakan perhitungan Center-of-Gravity (CoG) seperti ditunjukkan pada Persamaan 2. CoG dihitung berdasarkan nilai rata-rata dari koordinat piksel pada area daun terdeteksi pada masing-masing sumbu $\mathrm{x}$ dan y. Terdapat dua parameter statistik yang diambil untuk merepresentasikan jarak semua tepian ke titik tengah, yakni Median dan Standar Deviasi. Nilai median dipilih sebagai representasi rata-rata jarak tanpa terpengaruh oleh outliers. Nilai Standar Deviasi dipilih untuk menunjukkan variasi jarak tersebut. Untuk mengatasi pengaruh variasi ukuran daun, maka fungsi statistik yang digunakan yakni median dan standar deviasi akan di-normalisasi menggunakan luas area bounding box $A_{R}$. Contoh hasil $C o G$ dari daun terdeteksi pada Gambar 5 beserta tepian-nya dapat dilihat di Gambar 9 dimana CoG ditunjukkan sebagai titik merah.

$$
\operatorname{CoG}=\left[\frac{1}{N} \sum_{i=1}^{N} x_{i}, \frac{1}{N} \sum_{i=1}^{N} y_{i}\right]
$$
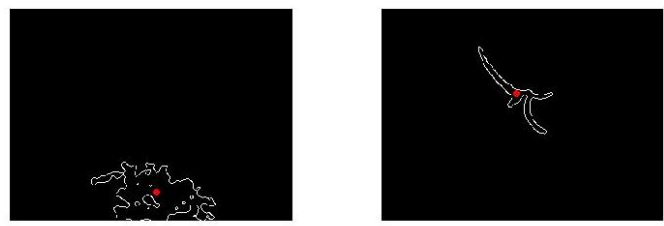

Gambar 9. CoG (titik merah) dan tepian dari daun terdeteksi

Fitur ketiga yang digunakan adalah Distance Transform function yakni fungsi statistik yang diambil dari perhitungan distance transform area daun terdeteksi. Fitur ini dipilih sebab bentuk daun tanaman bawang yang pipih memiliki perbedaan distance dari piksel background terdekat dibandingkan bentuk daun gulma yang bulat. Distance transform juga dipilih sebab fitur ini dapat mendefinisikan bentuk tanpa terpengaruh oleh rotasi (Fitriyah, H., Budi, A.S., 2019). Distance Trasnform pada gambar biner adalah jarak atau distance dari setiap piksel dalam area objek terhadap piksel terdekat dari background. Perhitungan distance yang dipilih adalah Euclidian distance. Fungsi statistik yang digunakan adalah Median dan Standar Deviasi. Median menunjukkan rata-rata distance yang tidak terpengaruh oleh outlier sedangkan standar deviasi menunjukkan seberapa variatif distance-nya. Untuk mengatasi pengaruh variasi ukuran daun, maka fungsi statistik yang digunakan yakni median dan standar deviasi akan di-normalisasi menggunakan

\begin{tabular}{|c|c|c|c|}
\hline $\begin{array}{l}\mathbf{0}_{(1,1)} \\
\mathbf{n}\end{array}$ & $\begin{array}{l}\mathbf{0} \\
(1,2)\end{array}$ & $\begin{array}{l}\mathbf{0} \\
(1,3)\end{array}$ & $\begin{array}{l}\mathbf{0} \\
(1,4)\end{array}$ \\
\hline $\begin{array}{l}\mathbf{1} \\
(2,1)\end{array}$ & $\begin{array}{l}\mathbf{0} \\
(2,2)\end{array}$ & $\begin{array}{l}\mathbf{0} \\
(2,3)\end{array}$ & $\begin{array}{l}\mathbf{0} \\
(2,4)\end{array}$ \\
\hline $\mathbf{1}$ & $\begin{array}{l}\mathbf{1} \\
(3,2)\end{array}$ & $\begin{array}{l}\mathbf{0} \\
(3,3)\end{array}$ & $\begin{array}{l}\mathbf{0} \\
(3,4)\end{array}$ \\
\hline 1 & $\mathbf{1}$ & $\overrightarrow{\mathbf{O}}_{(4,3)}$ & $\begin{array}{l}\mathbf{0} \\
(4,4)\end{array}$ \\
\hline
\end{tabular}
ukuran luas bounding box $A_{R}$.

\begin{tabular}{|c|c|c|c|}
\hline $\begin{array}{l}\mathbf{0} \\
(1,1) \\
\end{array}$ & $\begin{array}{l}\mathbf{0} \\
(1,2)\end{array}$ & $\begin{array}{l}\mathbf{0} \\
(1,3) \\
\end{array}$ & $\begin{array}{l}\mathbf{0} \\
(1,4) \\
\end{array}$ \\
\hline $\begin{array}{l}\mathbf{1}_{(2,1)} \\
\end{array}$ & $\begin{array}{l}\mathbf{0} \\
(2,2)\end{array}$ & $\begin{array}{l}\mathbf{0} \\
(2,3)\end{array}$ & $\begin{array}{l}\mathbf{0} \\
(2,4)\end{array}$ \\
\hline $\begin{array}{l}\mathbf{1} \\
(3,1)\end{array}$ & $\begin{array}{l}\mathbf{1} \\
(3,2)\end{array}$ & $\begin{array}{l}\mathbf{0} \\
(3,3)\end{array}$ & $\begin{array}{l}\mathbf{0} \\
(3,4) \\
\end{array}$ \\
\hline $\begin{array}{l}\mathbf{2} \\
(4,1)\end{array}$ & $\mathbf{1}_{(4,2)}$ & $\begin{array}{l}\mathbf{0} \\
(4,3)\end{array}$ & $\begin{array}{l}\mathbf{0} \\
(4,4)\end{array}$ \\
\hline
\end{tabular}

distance $[(4,1),(4,3)]=\sqrt{(4-4)^{2}+(1-3)^{2}=2}$

Gambar 10. Contoh perhitungan distance transform untuk piksel pada koordinat $(4,1)$
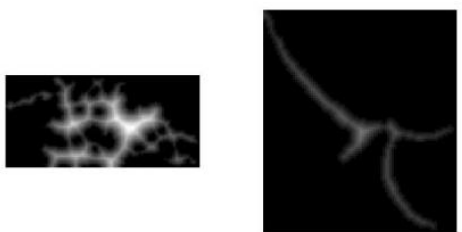

Gambar 11. Distance Transform dari daun terdeteksi 
Dari 3 fitur tersebut, terdapat 5 nilai yang akan digunakan sebagai input dari klasifikasi, yakni: (1) Rectangularity, (2) Normalised Median of Edge-tocenter distance, (3) Normalised Standard Deviation of Edge-to-center distance, (4) Normalised Median of Distance Transform, dan (5) Normalised Standard Deviation of Distance Transform. Normalisasi berdasarkan luas area bounding box $A_{R}$ dilakukan guna mengatasi variasi ukuran dari tanaman dan gulma.

\subsection{Klasifikasi menggunakan Jaringan Syaraf Tiruan (JST)}

Ketiga fitur bentuk yang telah di-ekstraksi kemudian diumpankan ke metode klasifikasi. Metode Jaringan Syaraf Tiruan atau Artificial Neural Network dipilih dalam penelitian ini sebab metode tersebut sering digunakan untuk memodelkan hubungan non-linier antara input dan output. Metode ini juga sesuai diterapkan di embedded system sebab tidak perlu memasukkan data latih ke dalam programnya seperti dengan metode KNN atau SVM.

Ukuran node dapat disesuaikan atau ditambah untuk meningkatkan akurasi. Penelitian ini menggunakan Shallow Neural Network yang terdiri dari hanya 1 Hidden layer karena proses feature extraction telah dilakukan sebelumnya. Jaringan yang dipilih adalah Multi-Layer Perceptron dimana setiap node pada input layer, hidden layer, dan output layer terhubung secara penuh atau yang disebut sebagai fully-connected.

Proses Training dalam JST digunakan untuk meng-update bobot antar node dan bias yang ditambahkan pada node hidden layer dan output layer. Proses training dilakukan menggunakan pemrograman Matlab yang menggunakan prinsip gradient decent untuk meng-update bobot dan bias hingga nilai iterasi berikutnya tidak banyak berbeda dari bobot dan bias iterasi sebelumnya atau yang disebut sebagai kondisi convergence.

\section{PENGUJIAN DAN PEMBAHASAN}

Pada input layer dari arsitektur JST dalam penelitian ini terdapat 5 node sebagaimana nilai fitur yang di-ekstraksi dari setiap tanaman atau gulma yang terdeteksi. Pada output layer terdapat 1 node dimana tanaman daun bawang diberi nilai 1 dan gulma Cemplonan diberi nilai 0. Total data yang digunakan dalam penelitian ini adalah 149 tanaman terdeteksi dari 78 gambar yang diambil. Tabel dari data yang digunakan dalam penelitian ini ditunjukkan pada Tabel 1. Kelas tanaman daun bawang sebanyak 97 data dan kelas gulma Cemplonan sebanyak 52 data. Sebanyak $70 \%$ dari data digunakan sebagai data latih, 15\% untuk data validasi dan $15 \%$ untuk data uji.

Tabel 1. Data 5 fitur dari 149 tanaman terdeteksi

\begin{tabular}{|c|c|c|c|c|c|c|}
\hline \multirow{2}{*}{ No. } & \multicolumn{5}{|c|}{ Fitur } & \multirow{2}{*}{ Kelas } \\
\hline & (1) & (2) & (3) & (4) & (5) & \\
\hline 1 & 0.5124 & 0.5455 & 0.2955 & 0.0455 & 0.0276 & 1 \\
\hline 2 & 0.1309 & 0.4386 & 0.2719 & 0.0175 & 0.0106 & 1 \\
\hline 3 & 0.5949 & 0.5857 & 0.2286 & 0.0515 & 0.0414 & 0 \\
\hline 4 & 0.2576 & 0.4286 & 0.2540 & 0.0317 & 0.0158 & 1 \\
\hline 5 & 0.5595 & 0.5000 & 0.2838 & 0.0302 & 0.0178 & 1 \\
\hline$\ldots$ & $\ldots$ & $\ldots$ & $\ldots$ & $\ldots$ & $\ldots$ & $\ldots$ \\
\hline 145 & 0.5161 & 0.4805 & 0.2208 & 0.0367 & 0.0305 & 0 \\
\hline 146 & 0.4186 & 0.4737 & 0.2632 & 0.0351 & 0.0196 & 1 \\
\hline 147 & 0.2018 & 0.4805 & 0.2078 & 0.0290 & 0.0270 & 0 \\
\hline 148 & 0.2444 & 0.5818 & 0.2727 & 0.0257 & 0.0125 & 1 \\
\hline 149 & 0.4341 & 0.4872 & 0.2564 & 0.0256 & 0.0141 & 1 \\
\hline
\end{tabular}

Dari proses training dengan 6 node pada Hidden Layer didapati akurasi proses validasi sebesar $100 \%$ dan akurasi proses uji atau testing sebesar $96,45 \%$. Bobot dan bias yang ditemukan dapat dilihat pada Tabel 2 untuk nilai bobot Input Node ke Hidden Node, Tabel 3 untuk nilai bobot Hidden Node ke Output Node, Tabel 4 untuk nilai Bias dari Hidden Node, dan Tabel 5 untuk nilai Bias dari Output Node.

Tabel 2. Nilai bobot Input Node ke Hidden Node

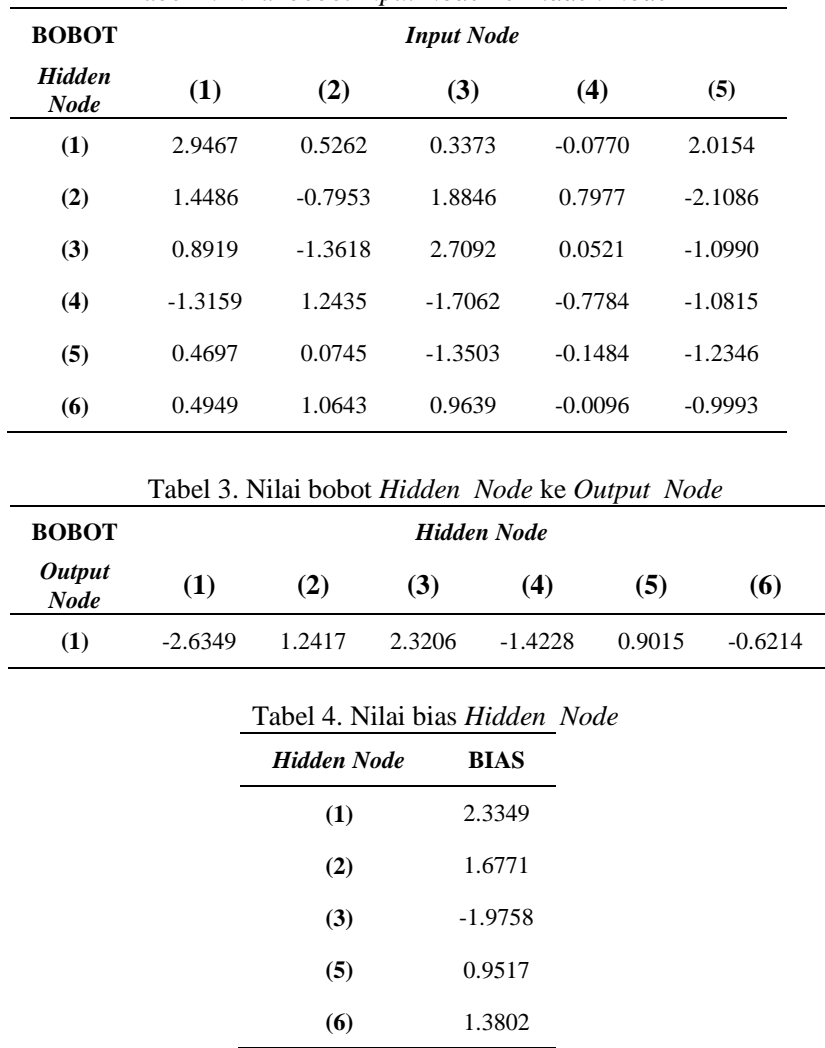




\begin{tabular}{cc}
\multicolumn{2}{c}{ Tabel 5. Nilai bias Output Node } \\
Output Node & BIAS \\
\hline (1) & 0.7741 \\
\hline
\end{tabular}

Akurasi dari arsitektur JST tersebut juga dibandingkan dengan metode klasifikasi dasar lain yang umum digunakan yakni Naive Bayes dan $K$ Nearest Neighbours (KNN). Metode Naive Bayes mengelompokkan data berdasarkan Peluang. Metode ini menghitung peluang data tersebut pada setiap kelas lalu mengelompokkannya kepada kelas dengan peluang tertinggi. Metode K-Nearest Neighbours (KNN) mengelompokkan data berdasarkan kelas data yang dekat dengannya. Metode ini mendefinisikan tetangga sebagai data dengan jarak atau distance kecil lalu melakukan voting kelas dari data-data berjarak dekat darinya sejumlah $\mathrm{K}$. Akurasi Naive Bayes dan K-Nearest Neighbours (KNN) ditentukan menggunakan metode $K$-Fold Cross Validation dengan jumlah fold sebanyak 5 yang diterapkan pada 149 data daun terdeteksi di Tabel 1. Hasil pengujian dari ketiga metode tersebut dapat dilihat pada Tabel 6.

Tabel 6. Perbandingan Akurasi Pengujian dengan metode KNN, Naïve Bayes dan JST

\begin{tabular}{llrr}
\hline \multicolumn{1}{c}{ Metode } & & Akurasi Pengujian (\%) \\
\hline KNN & & 3 & 86.58 \\
& Jumlah K & 5 & 87.92 \\
& & 7 & 83.89 \\
\multirow{2}{*}{ Nä̈ve Bayes } & & & 79.19 \\
\multirow{2}{*}{ JST } & & & \\
& Jumlah & & \\
& Hidden & 6 & \\
& Neuron & & \\
\hline
\end{tabular}

Dari Tabel 6 tersebut dapat dilihat bahwa metode JST memiliki akurasi tertinggi yakni 95.46\%. Metode KNN memberikan akurasi terbaik pada K sejumlah 5 yakni sebesar $87.92 \%$. Metode Naive Bayes memberikan akurasi terendah yakni 79.19\%. Hal ini menunjukkan bahwa klasifikasi tanaman/gulma berdasarkan fitur bentuk dimana bentuk dan ukuran sangat bervariasi lebih akurat dengan menggunakan metode JST.

\section{KESIMPULAN DAN SARAN}

Klasifikasi tanaman dan gulma dibutuhkan untuk melakukan identifikasi gulma pada robot penyemprot herbisida. Penelitian ini telah membuat algoritma klasifikasi tanaman dan gulma lokal Indonesia yakni daun bawang dengan gulma Cemplonan (Drymaria Cordata) menggunakan metode Jaringan Syaraf Tiruan (JST) dengan akurasi yang tinggi. Fitur bentuk yang digunakan sebagai input klasifikasi adalah Rectangularity, Edge-tocenter Function, dan Distance Transform Function.
Dengan hasil yang baik tersebut, maka penelitian selanjutnya adalah menerapkan algoritma yang telah dibuat ini pada sebuah robot penyemprot herbisida.

\section{UCAPAN TERIMA KASIH}

Penelitian ini merupakan hasil riset pendanaan Hibah Penelitian Pemula (HPP), lembaga Penelitian dan Pengabdian Masyarakat (LPPM), Universitas Brawijaya tahun 2020.

\section{DAFTAR PUSTAKA}

APRIADI, W., SEMBODO, D. R., \& SUSANTO, H. (2013). Efikasi Herbisida 2,4-D Terhadap Gulma pada Budidaya Tanaman Padi Sawah (Oruza Sativa). Jurnal Agrotek Tropika, 1(3), p.269-276. DOI: http :// dx.doi.org/ 10.23960/jat.v1i3.2040

BARUS, E. (2003). Pengendalian Gulma di Perkebunan, Efektivitas dan Efisiensi Aplikasi Herbisida. Kanisius.

BAWDEN, O., KULK, J., RUSSELL, R., MCCOOL, C., ENGLISH, A., DAYOUB, F., \& PEREZ, T. (2017). Robot for weed species plant-specific management. Journal of Field Robotics, 34(6), p.1179-1199. DOI: https://doi.org/10.1002/rob.21727

BEGHIN T., COPE J.S., REMAGNINO P., BARMAN S. (2010). Shape and Texture Based Plant Leaf Classification. Advanced Concepts for Intelligent Vision Systems. ACIVS 2010. Lecture Notes in Computer Science, vol 6475. Springer, Berlin, Heidelberg. DOI: https://doi.org/DOI: 10.1007/978-3-642-17691-3_32

FITRIYAH, H., SETIABUDI A., (2019). Outlier Detection in Object Counting based on Hue and Distance Transform using Median Absolute Deviation (MAD). Prosiding International Conference on Sustainable Information Engineering and Technology (SIET). DOI: https://doi.org/ DOI: 10.1109/SIET48054.2019.8985993

KADIR, M. (2007). Efektifitas Berbagai Dosis dan waktu Aplikasi Herbisida 2,4 Dimetilamina Terhadap Gulma Echinocola Colonum, Echinocloa Crusgali dan Cyperus Iria pada Padi Sawah. Jurnal Agrisistem, 3(1), p.5349.

KADIR, A., NUGROHO, L.E., SUSANTO, A., SANTOSA, P.I. (2011). Leaf Classification Using Shape, Color, and Texture Features. International Journal of Computer Trends and Technology, 1(3), P.225-235

MANGOENSOEKARJO, S., \& SOEJONO, A. (2019). Ilmu Gulma dan Pengelolaan Pada Budi Daya Perkebunan. UGM Press. 
MINGQIANG, Y., KIDIYO, K. JOSEPH, R. (2008). A Survey of Shape Feature Extraction Techniques, Pattern Recognition Techniques, Technology and Applications. Peng-Yeng Yin, IntechOpen. DOI: https://doi.org/ 10.5772/6237

MOENANDIR, J. (2010). Ilmu Gulma. UB Press.

PURNAMASARI, C., TYASMORO, S. Y., \& SUMARNI, T. (2017). Pengaruh Teknik Pengendalian Gulma pada Tanaman Padi (Oryza Sativa L.). Jurnal Produksi Tanaman, 5(5), p.870-879.

SARVINI, T., SNEHA, T., SUKANYA, G. G., SUSMITHA, S., \& KUMARASWAMY, R. (2019). Performance Comparison of Weed Detection Algorithms. International
Conference on Communication and Signal Processing. India. DOI: https://doi.org/10.1109/iccsp.2019.8698094

SLAUGHTER, D., GILES, D., \& DOWNEY, D. (2007). Autonomous robotic weed control systems: A review. Computers and Electronics in Agriculture, 61(1), p.63-78. DOI: https:// doi.org/ 10.1016/ j.compag.2007.05.008

SMITH, A.R., 1978. Color gamut transform pairs. Prosiding the 5th annual conference on Computer graphics and interactive techniques. Association for Computing Machinery, p.12-19. DOI: https://doi.org/10.1145/800248.807361 